\title{
Koncept i "svojstva" naravi ljudske osobe u onto-antropološkim i etičkim izazovima i kritikama razvoja umjetne inteligencije
}

\author{
Mislav Kutleša*, Josip Dolič**
}

\begin{abstract}
Sažetak
U radu je s filozofsko-teološkoga gledišta prikazano područje umjetne inteligencije. Ukazuje se na onto-antropološke i etičke izazove u suvremenim inženjerskim $i$ socijalnim pothvatima u kojima dostojanstvo i sigurnost ljudske osobe mogu biti dovedeni u pitanje. Njezina svakodnevna sve učestalija i šira primjena $i$ raznolikost implementiranja rezultirala je potrebom cjelovitoga i kritičkoga osvrta, ukazujući na opasnosti i dalekosežnost posljedica koje bi mogle nastati ako se pojavnost umjetne inteligencije ne bi vrjednovala, regulirala i primjenjivala odgovorno.
\end{abstract}

Ključne riječi: umjetna inteligencija; antropologija; etika; moralni status; osoba; sloboda; volja; odgovornost; izazovi; robotika

\section{Uvod}

Pitanje na koje tražimo odgovor u ovom radu glasi: Mogu li humanoidni roboti s umjetnom inteligencijom posjedovati status osobe, a time i pravno-moralnu zaštitu? Iskustvo nam govori kako je tehnologija postala važan i neizostavni element koji u mnogočemu olakšava individualni i društveni život ljudske zajednice. Dovoljno je obratiti pozornost na to čime se svakodnevno služimo kako bismo izvršili svoje obveze. Tehnologija je, možemo reći, postala neizostavni saveznik u razvoju i oblikovanju života društva. Unutar toga preobilja tehnoloških ponuda i mogućnosti nailazimo na mnoge izazove i razloge propitivanja o tom što se uistinu zbiva s čovjekom, što je čovjek unutar obilja e-proizvoda, e-ponuda, e-usluga, te što nam donosi e-budućnost $\mathrm{u}$ interakciji s umjetnom inteligencijom (Balaž i Ninčević, 2019, 6). Društvo, nesumnjivo je, postaje mješavina fizičkih i virtual-

* Doc. dr. sc. Mislav Kutleša, Katolički bogoslovni fakultet Sveučilišta u Zagrebu. Adresa: Vlaška 38, 10000 Zagreb, Hrvatska. ORCID iD: https://orcid.org/0000-0003-1248-9977. E-adresa:mkutlesakbf@gmail.com

** Josip Dolić, mag. theol. Adresa: Kardinala Alojzija Stepinca 4, 31551 Belišće, Hrvatska. ORCID iD: https://orcid.org/0000-0002-0855-3801. E-adresa: josipdolic3@gmail.com 
nih iskustava, i u tom leži čitava plejada izazova digitalizacije društva (Nikodem, 2003, 36-40). Uslijed radikalne tehnicizacije života i međuljudskih odnosa čovjek sve više osjeća moralnu dužnost i nužnost odgovoriti pozivu u sebi, svojega bića, na način da iznova traži i razumijeva samoga sebe kako ne bi izgubio one nijanse koje zapravo nisu sekundarni dijelovi njegove osobe i osobnosti, nego inherentna i neodvojiva sastavnica bitna za određenje i oblikovanje njegove osobe (Benanti, 2018, 41).

U novije vrijeme to traženje zadobiva sasvim novo i dublje moralno-antropološko značenje na području razvoja umjetne inteligencije. Ne uzimajući pojam umjetne inteligencije "zdravo za gotovo", potrebno je zapitati se zašto je i kako nastao termin umjetna inteligencija te može li robot s umjetnom inteligencijom imati status osobe. Već sam termin kazuje bitno svojstvo te tehnologije, odnosno da je tehnička "inteligencija" uvijek samo umjetna, a time uvijek ostaje kopija koja po svojoj naravi ne može, ma koliko tehnologija bila napredna, doživjeti ključan i nužan kvalitativni "antropološki skok" da bi u njoj zaživjela duhovna dimenzija stvora u kojega bi razum i sloboda bili konstitutivni i inherentni dio života. Možda nam se čini suvišnom i bespredmetnom rasprava o umjetnoj inteligenciji i njezinu razvoju, no to nikako ne bi bilo točno, osobito ako uzmemo u obzir revolucionarno iznašašće tehnologije na tom području: robot Sophie, koji već sada gotovo uživa nezamislivu pažnju te pravnu i moralnu zaštitu. Iskustvo nam govori da je, vrijednosno gledajući, robotika prestigla svojega proizvođača te stekla ona prava o kojima se još uvijek raspravlja kada govorimo o ljudskom životu i statusu (pravo na život i tretiranje kao osobe od začeća i pravo na rad). Ono za ljudsku vrstu predstavlja antropološki promašaj koji kreće od eksplicitnoga nijekanja prava na život i zaštiti ljudske osobe u početnoj fazi egzistencije (majčinoj utrobi). Riječ je fragmentiranom pogledu na čovjeka, čija vrijednost ovisi o trenutačnim modnim, tehnološkim, ekonomskim, medicinskim i drugim okolnostima, što je u potpunom neslaganju s integralnim pogledom na čovjeka u kojem čovjek jest i ostaje vrijednost u sebi i za sebe (DP br. 3-5).

S druge pak strane termin inteligencija imao vrlo široko značenje te nudi izvanrednu sposobnost suočavanja u rješavanju uočenih problema te mogućnošću snalaženju u novim izazovima do tada neproživljenih. Aspekti kojima se služi su intuicija, razum, rasuđivanje, određena kreativnost, usmjerenost k cilju zadatka, određeno znanje te sposobnost razumijevanja uzročno-posljedičnih veza, s tim da se upravo takva ljudska inteligencija manifestira na dva načina: komunikacijom i učenjem. Provodeći kritičku analizu umjetne inteligencije, Eric Sadin (2019) ukazuje na to kako tehnologija, sve više namećući se čovjeku, prestaje biti njegov saveznik. Tu alarmantnu situaciju od antropološke i etičke važnosti obrazlaže u djelu Critica della ragione artificiale.

Stoga je cilj ovoga rada istaknuti narav ljudske osobe u svjetlu zakonitosti koje, s jedne strane, čovjeku daju specifičan identitet ili status, a s druge strane predstavljaju svojstva i bitne temelje inherentnoga poriva za samoostvarenjem i samoodređenjem. Drugim riječima, cilj je rada istaknuti narav ljudske osobe kao dinamičnu zakonitost po kojoj se utvrđuje odrednica "biti ljudska osoba”, a 
posljedično i pravna i moralna zaštita, kao i zakonitost po kojoj se ista ostvaruje i određuje. Naime, narav nije nešto pasivno u osobi, nego dinamika po kojoj se osoba ostvaruje i živi (Fukuyama, 2003, 130). Narav je zakonitost osobe u njezinu kompletnom duhovno-tjelesnom "sastavu" i "sustavu" djelovanja i življenja, koju čovjek može samo i jedino doživljavati kao "otajstvo" koje stoji izvan dosega njegova stvaralačkoga djela. Za njega samoga ono je neostvariva želja, a ostvarivo samo Onomu od koga je sve i za koga je sve — Boga, Počelo i Izvor Života. Stoga je cilj ovoga rada doprinijeti produbljivanju smisla i značenja ljudske naravi, ali u svjetlu bio-psiho-socijalne i moralne zakonitosti s ciljem oblikovanja ljudskoga individualnoga i društvenoga života.

\section{1. "Biti osoba” и ozračju razvoja umjetne inteligencije}

Opće je poznato na koji se način termin osoba interpretira ili definira u suvremeno doba, kao i koji sve čimbenici utječu na to (Kovač, 2014, 15). Krećemo se u, takoreći, već izlizanom bioetičkom, ne nužno samo znanstvenom, ${ }^{1}$ vrijednosnom kontekstu, ali i uvijek novom i aktualnom s obzirom na nove okolnosti u kojima "biti osoba" ili imati "svojstva" osobe iznova biva izloženo analitičkoj i kritičkoj prosudbi i potvrdi, ili negaciji, onoga što je čovjek u sebi, odnosno u svojoj bîti, u svojoj naravi, a po čemu se bitno i nepremostivo razlikuje od drugih bića, napose od umjetne inteligencije. Iako u novije vrijeme taj termin pobuđuje snažne rasprave na području filozofije, teologije i bioetike, ipak je poznato kako termin osoba u kršćanskoj tradiciji nije predstavljao neki epitet ili samo nešto što definira i određuje čovjeka samo izvana (na biorazini), nego ukazuje na ključnu činjenicu kako "biti osoba" počiva i na određenim unutarnjim počelima, odnosno karakteristikama. Konkretnije, na naravi ljudskoga bića u njegovoj biološkoj i duhovnoj razini. Tomu u prilog ide izjava Matulića $(2009,192)$ u analizi pastoralne konstitucije Gaudium et spes: »Osoba je nositelj apsolutne vrijednosti, jer svoje bivstvovanje duguje božanskom principu bivstvovanja«. Ono jest privilegij, kako ga i danas zastupnici laicističke bioetike uprizoruju (Aramini, 2009, 39-42), ali privilegij koji vrijednosno utemeljenje ima u naravi ljudskoga bića, odnosno u onom što ljudsko biće jest u sebi samom.

Dakle, možemo li robote s umjetnom inteligencijom smatrati osobom u najdubljem smislu toga antropološkoga i etičkoga vrijednosnoga pojma i kako? Odgovore na to pitanje nalazimo u dvama relevantnim znanstvenim disciplinama: teologiji i filozofiji, svaki opet iz svoje perspektive, iako ne nužno suprotstavljene. Iz teološke perspektive već je od rana poznat nauk o čovjeku kao slici i prilici Božjoj (GS, br. 14-17). Naime, »za kršćansku teologiju čovjek je osoba sam u sebi i kao takav ima svoje ljudsko i kršćansko dostojanstvo. Njemu je život darovan i on nastoji taj život čuvati, razvijati i dovesti ga do punine kako bi mogao

1 Želimo ukazati na činjenicu kako se rasprava o izrazu "biti osoba" ne vodi isključivo u znanstvenoj areni, nego poprima sve šira područja rasprave, postaje predmet rasprave u široj javnosti i na neznanstvenim područjima, pa čak i na ulicama (primjerice akcija 40 dana za život). 
postići puninu života u svome Bogu. To znači da je čovjek živi subjekt koji se nastoji razviti, moralno poboljšati. Stoga on i ima svoj etički put, svoje vrednote i pravila ponašanja koja mu dolaze iz naravi i objave« (Tomašević, 2006, 409). U navedenoj Tomaševićevoj izjavi posebno se zaustavljamo pred onim što je za čovjeka egzistencijalno vrijedno i određujuće — »voditi život do punine «, »steći puninu života«, što ga kršćanin nalazi u Bogu, izvoru i konačnoj svrsi egzistencije (EV, br. 32-36). To znači da je narav ne samo temelj, nego i duhovno-moralna odrednica, odnosno ono što predstavlja načelo moralnoga djelovanja u kojem čovjek spoznaje, potvrđuje, objavljuje i ostvaruje samoga sebe kao sliku i priliku Božju kroz trajnu otvorenost i komunikaciju s Bogom. Dakle, narav nesumnjivo posjeduje normativnu vrijednost (Matulić, 2009, 504). Vlastita narav, kao razumne duše, daje mu mogućnost da participira na božanskom blaženstvu (CCE br. 1934). Već na samom početku ovoga teološkog diskursa spoznajemo kako je narav, shvaćena u duhovno-moralnom smislu, a ne samo biološkom, inherentna čovjeku te stvara put i okvire samoostvarenja ljudske osobe.

U filozofskoj perspektivi prožimaju se četiri karakteristike/svojstva osobe, antropološka svojstva koje čine okosnicu bioetike katoličkoga nadahnuća, tj. da je osoba: a) individualne; b) supstancije; c) razumske; d) naravi. Dakle, osoba nije samo narav, jer to ima i drugo biće, nije samo supstancija, jer to može biti i bilo koje drugo biće, niti je individua, jer to može biti i bilo koje drugo biće, nego je jedinstvo navedenih elemenata: individua — supstanca — narav — razum. Ljudska je osoba individualna supstancija koja posjeduje razumsku narav (Basti, 2008, 319-320). Prema tome, ključan pojam za obradu i dalje ostaje narav, i to shvaćena u dvojakom smislu: u smislu identiteta, tj. onoga što čovjek u samom sebi jest u psiho-tjelesnoj kondiciji, ali i u smislu vlastite moralnosti u djelatnom smislu. Drugim riječima, pristupamo čovjeku kao osobi u njegovu "biti” i "djelovati”, što je u suodnosu i međusobno se ne isključuje. Slično nam govori i filozofska antropologija, koja postavlja pitanje o čovjeku s obzirom na njegovu bît i bitak. Čovjek je određen kao animal rationale i animal sociale, kao biće koje proizvodi i rabi oruđe, kao simboličko biće koje stvara simbole i koristi se njima, kao djelatno biće, radno biće, biće slobode, koje bira, govori, plače, koje se smije, putuje, koje se igra ili kao biće koje je po svojoj metafizičkoj odredbi duhovno (Halder, 2002, 23). Međutim, čovjeka je nemoguće svesti i tumačiti samo u okvirima pukih performansi, funkcionalnosti i produktivnosti, kako je slučaj kod umjetne inteligencije. Narav ljudskoga bića ukazuje na dublji smisao djelovanja. Ono je istovremeno vanjskoga i unutarnjega odjeka, jer je čovjek individualna metafizička supstancija koja promišlja samu sebe. Wojtyła u svojem kapitalnom djelu Osoba $i$ čin piše da ljudska narav, na kojoj počiva termin osoba, ukazuje na personalističku vrijednost ljudskoga djelovanja (Maj i Popović, 2014). U svojem djelovanju, iako je osoba upućena na određenu funkcionalnost i produktivnost $\mathrm{u}$ društvu, osoba je ipak neminovno upućena i na samu sebe jer djelovanjem širi vlastite horizonte, ona se obogaćuje i oplemenjuje u moralnom, duhovnom, intelektualnom i iskustvenom smislu. Čovjek svakim djelovanjem doživljava stanovitu unutarnju razvojnu promjenu, odnosno evoluciju, on se mijenja i napreduje. To nije slučaj 
kod umjetne inteligencije, čije djelovanje ne možemo isključiti, ali je to djelovanje upućeno ka pukoj provedbi zadataka, a nakon provedbe ostaje ono što je bila i prije, bez ikakvoga unutarnjega duhovno-moralnoga pomaka i obogaćenja. U svakom djelovanju osoba ne samo da se izražava, nego se istovremeno izgrađuje i ostvaruje. Naime, ta problematika daje naslutiti novi dualistički pristup i pogled na čovjeka, kako na ono što jest, tako i na ono što i kako čini, odnosno po kojim načelima djeluje i živi, te koja je svrhovitost njegove egzistencije i rada, o čemu danas uvelike ovisi vrijednosni sud o vrijednosti ljudske osobe (Pessina, 2010, 103-107). Stoga govor o dobru kod umjetne inteligencije nije moralna kategorija, nego isključivo funkcionalistička, na koju čovjek nije svediv.

Poznato nam je iz povijesti filozofije da je čovjek (grč. anthropos, lat. homo) izuzetak od svega u svijetu postojećega utoliko, »ukoliko on 1) može govoriti i misliti o svemu, o svijetu i samome sebi; ukoliko on 2) svoju opstojnost, svoj život i ponašanje nema automatski, nego tako što on istom kroz mišljenje i djelovanje mora odrediti i u djelo provesti način na koji je njegov svijet uređen te ono: što i tko on sam hoće i treba biti« (Halder, 2002, 63).

Nužno je stoga u raspravi imati na umu da narav označava načelo življenja i djelovanja, te da ljudsko djelovanje nije samo upućeno na vanjski svijet, nego je neminovno usmjereno i na čovjekov unutarnji, duhovni, svijet. Tako za čovjeka bitno vrijedi temeljna odrednica njegova postojanja: subjekt $\rightarrow$ načelo $\rightarrow$ djelovanje $\rightarrow$ subjekt, odnosno svijet oko nas. Bez subjekta nema ni djelovanja, a i djelovanje traži načela, odnosno predispozicije koje omogućuju smisleno djelovanje, a posljedično i samoostvarenje osobe i obogaćenje svijeta (Pietro, 2010, 79-80). Tu slobodno spomenemo i Rogera Penrosea (2004), koji je ustvrdio kako tehnologija elektronski kontroliranih kompjutoriziranih robota ne može osigurati razvoj umjetne konstrukcije stroja koji je doista inteligentan, stroja koji djeluje na temelju razumijevanja, a koji se ne bi kontrolirao putem algoritama. Zapravo, ljudska spoznaja i djelovanje predstavljaju nešto daleko više od logičke strukture algoritma, kako navodi u svojem djelu.

Ljepota i paradoks ljudskoga u tom je da čovjek, iako ograničeno biće, ima u nutrini svojega bića moć iskustva neograničenoga, beskonačnoga. A taj paradoks dolazi mu od Stvoritelja (Stein, 2011, 102-114). Robot nije i ne može biti čovjek u nastajanju, jer čovjek nije nešto što se može oponašati spajanjem ili kombiniranjem organskoga i anorganskoga, čovjeka i stroja. Biti čovjek dar je koji se prima.

Prema tome, govorimo o temeljnim onto-antropološkim postavkama kad je riječ o čovjeku, životu, rađanju i umiranju, a to su: bitno jedinstvo ljudske osobe, dostojanstvo ljudske osobe koja nikada ne smije biti objekt, nego i subjekt (Tomašević, 2011, 53). Na kraju, postavlja se i pitanje stvaranja duše. Je li izvorno životni dah životvoran uopće ostvariv u nekom stroju s inteligencijom kao i kršćansko poimanje besmrtnosti duše u odnosu na stroj koji ima svoje vrijeme trajanja? (Besnier, 1990, 28). 


\section{Vrijednost u jedinstvu tijela i duha u tehno-(bio)etičkom diskursu}

Potrebno je nadalje, s obzirom na narav, razgraničiti koja je to diferentia specifica koja osobu razlikuje od drugih bića ili stvari. Zaključno bismo mogli u promišljanje uključiti različite znanstvene discipline, no mi ćemo se ograničiti i pozivati na antropologiju (i filozofsku i teološku), koja postavlja ključno pitanje o istodobnosti i neodvojivosti postojanja tijela, duše i duha kod čovjeka. Pod vidom metafizičko-filozofske tradicije poimanje duha ponajprije smjera onomu čime se odlikuje čovjek time što je on kao konačno živo biće kadar prekoračiti granice koje su mu dane njegovom tjelesnošću i zahvaćati u vanjski mu svijet (Vuletić i Puljić, 2019, 303-305). Ljudski se život i djelovanje ne mogu vrjednovati u svjetlu performansi jer se čovjek u vlastitom djelovanju uključuje na dvostrukoj i jedinstvenoj razini: duhovnoj i tjelesnoj (Basti, 2008, 335; Brstilo, 2009, 293-294). Ljudsko djelovanje bitno se temelji na njegovoj naravi kao duhovnoga bića te ono nije u opreci s njegovom tjelesnom dimenzijom jer se kroz nju izražava, objavljuje i ostvaruje. Čovjek je u trajnom odnosu duha i tijela, kako unutar samoga sebe, tako i u komunikaciji s vanjskim mu svijetom. Na tom tragu otvara se pitanje može li, i kojim zahvatom, tjelesnost stroja (izvanjsko obličje nalik stvorenjima) ostvariti i komponente duha i duše. Kada se govori o funkcijama mozga, misli li se isključivo na sposobnost rasuđivanja i donošenja odluka? Mozak je ujedno organ koji utječe i upravlja hormonalnim sustavom, a ujedno hormonalni sustav određuje i čovjekovu spolnost.

Kada pogledamo vanjski izgled robota, najčešće uočavamo kopiranu ljudsku tjelesnost. Stoga se pitamo što stvorenost (ako ju se želi promatrati širom od čovjeka) čini živom. Ako si proizveo predmet, on je neživ, ali ako si uzgojio biljku ili životinju, one su žive. Što je dakle bitno svojstvo žive stvorenosti? Je li to samo sposobnost kretanja, govora, donošenja odluka, izvođenje zaključaka što sve odlikuje super-robota? Ili biti živ obuhvaća nešto što kao svoj opozit i protutežu ima smrt, odnosno konačnost bivovanja. Postojanje koje nije uvjetovano propadanjem materije briše pojam o vremenu kao ograničenosti postojanja. Neograničenost vremena pak otvara vrata bezvremenomu trajanju — besmrtnosti. Super-roboti nemaju staničnu strukturu niti su podložni zakonima starenja.

»Svaki tehnički problem ima i tehničko rješenje. Ne moramo čekati Drugi dolazak da bismo pobijedili smrt. Ako je smrt tradicionalno bila specijalnost svećenika i teologa, sada njihovu ulogu preuzimaju inženjeri« (Harari, 2017, 29). U tom smislu odnos tijela i duha nalazi se u novoj, a opet staroj, napetosti odnosa novoga i staroga, života i smrti, vremenskoga i bezvremenskoga, odnosno vječnoga. Kod čovjeka se ono na specifičan način odnosi na vrijednost i smisao života ako dođe do pojave psiho-tjelesnih poteškoća uslijed bolesti i usporenosti, tj. gubi li čovjek uslijed istih okolnosti metafizička svojstva, a čime bi se, eventualno, stvorili preduvjeti za isključivanje iz društva. Kršćanska nas predaja uči da je čovjek jedno u tijelu i duhu, te je kao takav u trajnom odnosu s Bogom (Nemet, 2003, 119-132). Njegova je narav, očito je, metafizička i transcendentalna, kako egzistencijalno tako i praktično (u smislu samoostvarenja u odnosu s Drugim i 
drugim). Štoviše, na smrt se više i ne gleda kao na metafizički misterij, a kamoli da ju se promatra u smislu vječnosti, vječnoga zajedništva sa Stvoriteljem. Becker tomu nadodaje ključnu kritiku s obzirom na neodvojivost duha i tijela, tj. da čovjek egzistira u jedinstvu tijela i duše. Štoviše, »duša se može ostvariti samo onda ako se u stvarnosti realizira s tijelom. Smrt nastupa onda kada se tijelo i duša odjeljuju jedan od drugoga « (Becker, 2015, 21).

Promatrajući super-robote s umjetnom inteligencijom nužno je pitati se je li dovoljna samo vanjska forma koja, ma koliko god savršeno kopirala, ipak ostaje kopija, te time podsjećajući na čovjeka da bi "super-robotu" bilo dano i priznato svojstvo osobe. Govoreći o vanjskoj formi koja savršeno podsjećajuća na čovjeka i u kojoj je ugrađeno mnoštvo kamera za kretanje i obavljanje funkcija, pitamo se nije li u ljudskom tijelu senzomotorika upravo ta koja kao organizacija upravlja osjetilima u svrhu njihova korištenja. Uzmemo li u obzir da »mozak u svakom trenutku organizira i integrira sve informacije koje se primaju osjetilima iz okoline ili iz vlastitoga tijela te tako kreira i daje potpunu sliku o okolnom svijetu « (Balaž i Ninčević, 2019, 24), tada nam se otvara horizont dubljega poniranja u iduće "svojstvo" naravi — odnos, biti u odnosu, ovisiti o odnosu, ostvarivati se u i kroz odnos. Dovoljno je spomenuti se tjelesnosti kao izvanjske datosti, spolnosti osobe, tj. spolne različitosti muškarca i žene na bio-psiho-socijalnoj i duhovnoj razini (PH br. 1). Ljudska bipolarna podjela u spolnosti stvara preduvjete razmnožavanju, ali opet ni razmnožavanje nije jedini vrijednosti kriterij naravi ljudske osobe, nego je riječ o načinu i unutarnjoj duhovnoj dimenziji spolnoga čina po kojem su osobe otvorene jedna drugoj u uzajamnom slobodnom i ljubavnom dijalogu darivanje-prihvaćanje. To pitanje nameće se prvenstveno zbog stvarnosti humanoidnih robota koji se koriste u svrhe brzorastuće sofisticirane tehnologije pornoindustrije te već sada postoje mnogi bordeli koji nude usluge "spolnih" užitaka između čovjeka (prvenstveno muške osobe) i humanoidnoga robota koji ima sve izvanjske karakteristike ženske osobe. Ta industrijska grana bilježi iznimni ekonomski rast, stoga pitanje seksa humanoidnih robota iziskuje da ne zaobiđemo to polje. I u tom smislu robotika ima samo jednu funkciju (još jedno funkcionalističko gledanje) — zadovoljiti čovjeka u seksualnoj požudi. Međutim, oslanjajući se na najdublju istinu o čovjeku, ne možemo zanemariti da razmnožavanje za čovjeka predstavlja određeni društveni ili religijski poziv, no (na)čin na koji se ono događa je jedinstven. Ljudska je narav takva da je u potpunosti strukturirana komunikacijski odnosno da je spolni čin duhovno-tjelesna komunikacija i dijalog muškarca i žene kroz koji učvršćuju zajedništvo, ali i upotpunjuju jedan drugoga (Hildebrand, 2010, 1-10; Spaemann, 2010, 1-23). Poštujući taj karakter kao inherentnu i neodvojivu stvarnost, čovjek ostvaruje i potvrđuje samoga sebe kao misleće biće, kao biće koje savješću i slobodom, mudrošću i razboritošću donosi odluke i planira život, što će biti vidljivije u nastavku. Drugim riječima, iako otvoren prema vanjskomu mu svijetu čovjek je neminovno otvoren i prema njemu unutarnjemu svijetu, stoga mu i djelovanje ne može biti vrjednovano isključivo kao funkcionalističko, kako je kod umjetne inteligencije, nego je bitno personalno, tj. antropološki vrijednosno. 


\section{Vrijednost kognitivne i društvene dimenzije ljudske osobe}

Čovjek ima svoju povijest. Prema Harariju ono što je započelo cijelu priču ono je što se naziva kognitivna revolucija. Kognitivna revolucija naziv je procesa u kojem je čovjek razvijao nove načine razmišljanja i komuniciranja. Ljudska su bića prirodno usmjerena na traganje za značenjem i smislom, no konačni rezultat toga traganja ne postiže se automatski. Također, nakon svakoga novoga učenja mora slijediti razdoblje procesuiranja, odnosno razmišljanja o tome što se iskusilo ili učilo, kako bi se stvorile veze s otprije poznatim, stekao dublji uvid i uočile dodatne mogućnosti skrivene u već postojećem iskustvu. Zna se da naš mozak radi istovremeno na više razina, procesirajući odjednom svijet riječi, boja, pokreta, emocija, oblika, zvukova, okusa, težina i mnogo toga drugoga. Vraćajući se na polje sposobnosti učenja mozga, tvrdimo da mozak uči jer je to njegova prirodna funkcija, a njegov je kapacitet za učenje neiscrpan.

U tu svrhu Balaž i Ninčević detaljno seciraju i analiziraju pojam cogito u kontekstu umjetne inteligencije: »Ovaj co ukazuje na neku vezanost uz nešto ili upućenost nečemu. Riječ agito dolazi od ago i označava nešto neprestano, stalno iznova, na nešto nagoniti ili k nečemu tjerati. A upravo ono ključno u cogito jest upravljenost spram nečeg određenog koja postaje usmjerenost. Ovo je važno iz razloga što humanoidni robot $\mathrm{s}$ umjetnom inteligencijom ne posjeduje percepciju unutar sebe, nutarnji proces, jasnu svjesnost sebe kao 'ja jesam, ja postojim' niti može uočiti vlastito tijelo, iako mu na neki način služi za komuniciranje s okolinom, kao objekt komunikacije vlastit samo njemu niti subjektivnu svijest o njemu (tijelu)« (Balaž i Ninčević, 2019, 110-115). Roboti i računala nemaju svijest jer, bez obzira na brojne sposobnosti kojima raspolažu, ne osjećaju ništa niti za čim žude. Po pitanju samosvijesti samo ljudi sebe razumiju kao trajna bića s prošlošću i budućnošću, možda samo zato što ljudi mogu rabiti jezik razmišljajući o svojim prošlim iskustvima i budućim postupcima. Dolazimo tako do polja znanja, kao rezultata spoznaje zasnovana na uvjerenosti u istinitost nekoga suda. Spoznaja je djelatnost ili proces, a znanje je rezultat toga procesa. Mozak, um i svijest sve to pripada živomu tijelu koje ima svoju refleksiju u svijetu. Upravo ta korelacija svijesti i svijeta potvrđena je spoznajom jer osjetilno primanje pobuđuje razum koji je istovremeno sredstvo, svrha, ali i učinak (Malović, 2007, 47-49). Promatrajući taj složeni proces koji se odvija na tako smislen način u svakom pojedincu, za pretpostaviti je da bilo koji ljudski proizvod neće moći doživjeti taj kvalitativni ontološki skok koji izvorno posjeduje čovjek.

Možemo li, stoga, takvu inteligenciju koja se realizira nad računalnim sklopovljem pridružiti tomu prostoru ljudskoga (Skansi, 2015, 407)? Ono ljudsko pod utjecajem prosvjetiteljstva povezujemo s racionalnošću, slobodnom voljom, autonomijom i samosviješću kao osnovama ljudskoga identiteta. Koje, dakle, svojstvo tehnologija treba imati da bi postala "inteligencija" u smislu ljudske inteligencije, tj. je li to uopće ostvarivo? Naime, sintagma "umjetna inteligencija" upućuje na to da su inteligencija i svijest nešto pridržano samo čovjeku, u kojem ono predstavlja fundamentalnu ontološku kategoriju (Balaž i Ninčević, 2019, 
102-105). Da bi se bilo osoba, a time i moralni subjekt, po Aristotelu je nužna mogućnost krjeposti kao okosnice ljudskoga (su)života. Oni koji tu mogućnost ne posjeduju su ili životinje, ili barbari, ili robovi, dakle nisu ljudi u punom smislu te riječi, tvrdi filozof. Samim time, ne priznaje im se status moralnoga subjekta, ni sva prava koja iz njega proizlaze. Krjepost je, čitamo iz Nikomahove etike, stanje s izborom, tj. promišljenom žudnjom za stvarima koje su u našoj moći, a na način na koji bi to učinila razborita osoba. Za prosudbu nečije krjeposti ključna je mogućnost izbora, tj. moment slobode (Aristotele, 2009, 125-131). Robot tu mogućnost nema. Zakon ili odredba ugrađena u njegovu matricu kao sastavni dio oduzima mu opciju slobodnoga izbora. On djeluje onako i za ono za što je zamišljen, i nikako drugačije. Prema njima je, naravno, moguće razviti simpatije, ali one se načelno ne razlikuju od sentimentalne vezanosti za primjerice komad pokućstva. U međuvremenu roboti ne stare i ne obolijevaju. Ne rađaju se, ne odrastaju (proizvode ih u željenoj dobi). Glavni razlog koji doprinosi njihovu statusu je njihova nemogućnost iskustva empatije, osjećaja ili emocija (Grgić, 2009). Empatija je, po definiciji, sposobnost razumijevanja značenja i bitnosti emocija i ponašanja druge osobe, uživljavanje u tuđe emocionalno stanje. Prema tome, robot se ne može smatrati aktivnim članom ljudske zajednice. Štoviše, on je u sebi isključen iz života zajednice.

Čini se, dakle, da ljudsko biće drži određeni položaj u odnosu na sve ostale žive oblike jer njegovo djelovanje, koje nije mehanički određeno genima, ima posljedice na ukupnost života i na činjenicu da se čovjek pojavljuje kao jedini koji je sposoban preuzeti odgovornost u svemiru, jedino biće sposobno odgovoriti na posljedice svojih postupaka. Taj uvjet, koji u nekim oblicima antropologije nosi naziv osobnoga stanja, temelji se na praktičnom odnosu koji čovjek ima sa sobom, odnosom koji pronalazi refleksni izraz, u povijesti svojih kultura, u svijesti da je moralno življenje, jedino, i u zajedničkom iskustvu biti moralna savjest. Čovjek od trenutka praktičnoga stjecanja sposobnosti samosvijesti i autonomije istovremeno stječe i sposobnost da stvara, a time i kreira svoju vlastitu budućnost. Time, dakako, ukazujemo na jedinstvenu sposobnost, među živima, da na djelotvoran i slobodan način odredi i usmjerava svoje djelovanje. Tako mogućnost slobode i moralne odgovornosti, kao i poznavanje obvezujućega karaktera te mogućnosti, čine temeljno moralno iskustvo čovjeka. Stoga čovjek, budući da je slobodan i odgovoran, osoba, živi tim ustavom u svojoj odluci i odlukama (Benanti, 2018, 64). Kognitivno je stanje kao specifičnost ljudskoga bića upravo izvor načina na koji je čovjek prilagodio i promijenio svoj način života u svijetu. Time dolazimo i do pitanja slobode kao istinske biti čovjeka, kojom je obilježen i time postavljen u jednu otvorenost. Ključno je da je pred njega stavljena zadaća da u toj ne-determiniranosti može odlučivati, uređivati i oblikovati svoju povijesnost u vremenu za vječnost, čime se, prvenstveno na području tehnologije i robotike, aktualizira zanemarena vrijednost i komponenta ljudske osobe — eshaton. 


\section{Zaključak}

Svjesni da gotovo sve bioetičke teme i rasprave u središtu svoje zbilje imaju čovjeka kao glavni predmet, tako ni ovo područje ne može zaobići staro pitanje koje uvijek iznova očituje snažnu polarizaciju u društvu s obzirom na ključno pitanje: Kada ljudsko biće postaje osoba? To je stvarnost s kojom se suočavamo i na području neuroznanosti i kibernetike. Tehnička dostignuća koja se nazivaju umjetna inteligencija sa svim svojim potencijalom i sposobnostima transformacije mogu radikalno promijeniti svijet koji poznajemo, a zapravo već i mijenjaju. Na provokativan način možemo reći da danas, prvi put u našoj povijesti, to je stroj koji nas poziva - i izaziva. Na nama je, kao čovječanstvu, pronaći odgovore, a ono će se dogoditi samo ako znamo uključiti i humanističke znanosti u stvaranje tih alata. No put stvarnoga nadanja oko istoga samo je jedan - obnoviti svijest o nepovredivoj i neporecivoj vrijednosti dostojanstva ljudske osobe u svim njezinim razvojnim fazama i svim životnim psiho-fizičkim, kulturalnim, ekonomskim i drugim okolnostima ljudskoga života prvenstveno kao vrijednosti u sebi i za sebe.

Dakle, može li robotika s umjetnom inteligencijom zaista prestići svojega proizvođača i zadobiti status osobe? Koliko je god odgovor u sebi vrlo jednostavan, ipak iskustvo pokazuje da ono iz mnogih ideoloških, funkcionalističko-profitabilnih razloga nije. Ako u raspravu uključimo stvarnost da je čovjek, gledajući antropološki i moralno, ponajprije vrijednost u sebi i za sebe, onda bi odgovor na prethodno pitanje bio negativan jer bi odgovor temeljili na naravi odnosno "svojstvima" naravi ljudskoga bića. Od prve do zadnje stranice sadržaja ovoga rada imali smo priliku primijetiti čitavu plejadu najrazličitijih pojmova ključnih u definiranju naravi i neporecive vrijednosti ljudske osobe, među kojima izdvajamo ono ključno: "voditi život do punine". Upravo nam je izraz "voditi do punine" otvorio horizonte ovoga istraživanja uviđajući stvarnu vrijednost čovječjega "biti" i "djelovati" kao osoba. To je u prvom redu njegova narav kao osobe, tj. jedinstvo duha i tijela, kognitivna moć, sposobnost za emocije i empatiju za drugoga, ali i svijest o stvorenoj stvarnosti oko sebe. Nadalje, kod čovjeka ne izostaje metafizičko-duhovna dimenzija, koja je ukorijenjena u svakoj osobi jer je stvorena na sliku Boga Stvoritelja, tj. umjetna inteligencija ne posjeduju u svojoj biti kvalitetu stvorenosti na sliku Božju, ma koliko uspješno pojavnosti umjetne inteligencije izvanjski oponašale čovjeka i stvorenja. Iz istih razloga umjetna inteligencija nema ni urođenu ni ugrađenu mogućnost postaviti si temeljna životna pitanja koja se u njoj zrcale kao životni poziv: od kuda dolazi, tj. za što je stvorena, zbog čega i za koga opstoji, odnosno živi, koja je problematika svjesnosti življenja uz pitanje patnje, križa i samopredanja za druge, te u konačnici kamo hodi, a to je za čovjeka vječni život i zajedništvo u Bogu. Upravo je u djelovanju najvažniji specifikum naravi ljudske osobe, specifikum koji ne ostvaruje ni jedno drugo biće, tj. da je u svojem djelovanju i subjekt i objekt istovremeno. Jedino je u čovjeka živo prisutan taj, takoreći, egzistencijalni paradoks: »Tko hoće život svoj spasiti, izgubit će ga, a tko izgubi život svoj poradi mene, naći će ga« (Mt 16,25). Ljudska 
je narav, gledano u svjetlu Kristove izjave, specifična u djelovanju i darivanju. Čitav je čovjek u svojoj usmjerenosti na samoostvarenje upućen na drugoga, i to ne samo da živi s drugim, nego da živi za njega. Za kršćanina to sadrži snažnu antropološku i moralnu vrijednost jer se darivanje Gospodinu ne ostvaruje bez darivanja čovjeku, a posebice onima koji su u velikoj nevolji i potrebi: gladni, žedni, oboljeli, stranci, goli, utamničeni (Mt 25,31-46).

\section{Literatura}

Aramini, Michele (2009). Uvod u bioetiku. Zagreb: Kršćanska sadašnjost.

Aristotele (2009). Etica Nicomachea: Testo greco a fronte. Milano: Bompiani.

Balaž, Zdenko; Ninčević, Marino (2019). Kognitivna kibernetika: Računska racionalnost misaonih sustava. Zagreb: Glas Koncila.

Basti, Gianfranco (2008). Filosofia dell'uomo. Bologna: Edizioni Studio Domenicano.

Becker, Patrick (2015). U stupici svijesti?: Duh i mozak u raspravi teologije, filozofije i prirodnih znanosti. Zagreb: Kršćanska sadašnjost.

Benanti, Paolo (2018). Le macchine sapienti. Bologna: Marietti.

Besnier, Jean-Michel (1990). Imaju li kognitivne znanosti pravo na dušu? Treći program hrvatskoga radija, 28, 139-147.

Biblija. Adalber Rebić, Jerko Fućak i Bonaventura Duda (ur.), Biblija: Stari i Novi zavjet s uvodima i bilješkama iz La Bible de Jérusalem. Zagreb: Kršćanska sadašnjost, 2003.

Brstilo, Ivana (2009). Tijelo i tehnologija u postmodernoj perspektivi. Socijalna ekologija, 18(3-4), 289-310.

CCE. Catechismus Catholicae Ecclesiae. Ivan Pavao II., Katekizam Katoličke crkve: Dorađeno izdanje. Zagreb: Hrvatska biskupska konferencija, 2016.

DP. Dignitas personae. Kongregacija za nauk vjere, Dignitas personae: Dostojanstvo osobe: Naputak o nekim bioetičkim pitanjima. Zagreb: Kršćanska sadašnjost, 2009.

EV. Evangelium vitae. Ivan Pavao II., Evangelium vitae: Evandelje života: Enciklika o vrijednosti i nepovredivosti ljudskog života. Zagreb: Kršćanska sadašnjost, 2003.

Fukuyama, Francis (2003). Our posthuman future: Consequences of the Biotechnology Revolution. London: Profile books.

Grgić, Lovro (2009). Što ako androidi zaista sanjaju električne ovce? Časopis studenata filozofije, 8(16-17), 74.

GS. Gaudium et spes. Drugi vatikanski koncil, Pastoralna konstitucija Gaudium et spes o Crkvi u suvremenom svijetu. U: Josip Turčinović (ur.), II vatikanski koncil: Dokumenti: Latinski i hrvatski (str. 620-768). Zagreb: Kršćanska sadašnjost, 1970.

Halder, Alois (2002). Filozofijski rječnik. Zagreb: Jurčić.

Harari, Yuval Noah (2017). Homo Deus: Kratka povijest sutrašnjice. Zagreb: Fokus komunikacije.

Hildebrand, Alice von (2010). Man and Woman: A Divine Invention. Florida: Sapientia.

Kovač, Nedjeljka s. Valerija (2014). Personalno-relacijska paradigma teologije Josepha Ratzingera / Benedikta XVI. Zagreb: Kršćanska sadašnjost.

Maj, Piotr; Popović, Petar (2014). Personalistička vrijednost ljudskog čina u filozofiji Karola Wojtyłe. Bogoslovska smotra, 84(4), 721-744.

Malović, Nenad (2007). Ljudsko dostojanstvo između znanosti i svjetonazora. Bogoslovska smotra, 77(1), 43-57.

Matulić, Tonči (2009). Metamorfoze kulture. Zagreb: Glas Koncila. 
Nemet, Ladislav (2003). Teologija stvaranja. Zagreb: Kršćanska sadašnjost.

Nikodem, Krunoslav (2003). Moderno društvo kao tehničko društvo: Društveno-povijesna priprema za razvoj neljudskih oblika života. Nova prisutnost, 1(1), 29-42.

Penrose, Roger (2004). Carev novi um. Zagreb: Izvori.

Pessina, Adriano (2010). La grammatica della vita umana e quella della democrazia. U: Congregazione per la dottrina della fede: Istruzione Dignitas personae su alcune questioni di bioetica: Commenti (str. 100-109). Città del Vaticano: Libreria Editrice Vaticana.

PH. Persona humana. Kongregacija za nauk vjere, Persona humana. Zagreb: Kršćanska sadašnjost, 2003.

Pietro, Leopoldo (2010). Antropologia tecnologia: Natura umana e cultura. U: Joseph Tham i Massimo Losito (ur.), Bioetica al futuro: Tecnicizzare l'uomo o umanizzare la tecnica? (str. 79-97). Città del Vaticano: Libreria Editrice Vaticana.

Sadin, Eric (2019). Critica della ragione artificiale. Paris: Luiss.

Skansi, Sandro (2015). Umjetna inteligencija i kompatibilizam: Mogućnost postanka slobodnog uma u determiniranom tijelu. Filozofska istraživanja, 30(3), 407-414.

Spaemann, Robert (2010). Essays on anthropology. Oregon: Cascade books.

Stein, Edith (32011). Znanost križa. Zagreb: Kršćanska sadašnjost.

Tomašević, Luka (2006). Bioetički izazovi: Izazovi globalne bioetike i biotehnologije. Bogoslovska smotra, 76(2), 395-415.

Tomašević, Luka (2011). Ontološko i funkcionalističko shvaćanje osobe: Bioetička rasprava. Crkva u svijetu, 46(2), 143-170.

Vuletić, Suzana; Puljić, Ana (2019). Dostojanstvo osobe u kontekstu kršćanske antropologije. Služba Božja, 59(3), 292-311. 
The Concept and »Features« of the Nature of the Human Person in Onto-Anthropological and Ethical Challenges and Critiques on the Development of Artificial Intelligence

\author{
Mislav Kutleša*, Josip Dolić**
}

\title{
Summary
}

This thesis presents a philosophical — theological point of view on artificial intelligence and superintelligence and has its starting point in the following question: »Can artificial intelligence claim the dignity of the human person? «The paper deals specifically with the problem of ethical questionability and the possibility of an anthropological dimension to artificial intelligence, in the full human sense, wholly and uniquely, with all the essential characteristics, characteristics of the human being and the dignity of the person. The paper deals particularly with the challenges within the social dimension because of the great utility, speed of work and profit increase owing to artificial intelligence. An increasing use and diversity in implementation from medicine, the military, computer science, robotics, the mobile industry and various other industries has resulted in the need for a comprehensive and critical review, especially in the onto-anthropological field because of the growing tendency to define artificial intelligence as a human person due to its performances and successes. We are dutibound to expand our horizons on the onto-anthropological values of the human person, especially his deepest mystical and social dimension, noting that his actions have internal values - not only external — which contribute to the development and enrichment of the spirit, both of the active subject and of the recipient at the same time. Therefore, the value of the human person is intrinsic and irreplaceable as concerns the development of another human person and also of human society.

Key words: artificial intelligence; anthropology; ethics; moral status; person; freedom; will; responsibility; challenge; robotics

* Mislav Kutleša, Ph.D., Assistant Professor, Faculty of Theology, University of Zagreb, Address: Vlaška 38, 10000 Zagreb, Croatia. E-mail: mkutlesakbf@gmail.com

** Josip Dolić, Mag. theol. Address: Cardinal Alojzija Stepinca 4, 31551 Belišće, Croatia. E-mail: josipdolic3@gmail.com 